\title{
STRIKE MISCONDUCT: AN ILLUSORY BAR TO REINSTATEMENT*
}

WHEN an employer refuses to bargain with a union representing the majority of his workers or otherwise commits an unfair labor practice ${ }^{1}$ that initiates a protest strike, the Labor Management Relations Act greatly restricts the employer's traditional right to discharge or discipline his employees. ${ }^{2}$ At the termination of the strike, the National Labor Relations Board will generally order reinstatement for all workers participating in the strike, even if the employer has hired permanent replacements, to prevent the employer from frustrating legitimate collective activity by his strike-provoking unfair labor practice. ${ }^{3}$ Where employees engage in misconduct, inhibiting the peaceful settlement of the labor dispute, the Board is faced with a conflict between two policies of the act in choosing its remedy. ${ }^{4}$ Thus, it is uncertain whether the Board will require

*Local 833, UAW-AFL-CIO v. NLRB, 300 F.2d 699 (D.C. Cir.), cert. denied sub nom. Kohler Co. v. Local 833, UAW-AFL-CIO, 370 U.S. 911 (1962).

1. As defined by Labor Management Relations Act (Taft-Hartley Act) \& 8, 61 Stat. 140 (1947), 29 U.S.C. § 158 (1958), amending National Labor Relations Act (Wagner Act) $\S 8$, 49 Stat. 452 (1935) [hereinafter cited as Taft-Hartley Act and Wagner Act, respectively].

2. Taft-Hartley Act $\$ 10$ (c), 61 Stat. 147 (1947), 29 U.S.C. $\$ 160$ (c) (1958), amending Wagner Act $\S 10(\mathrm{c}), 49$ Stat. 454 (1935), gives the NRLB authority both to order the employer to cease and desist from continuing an unfair labor practice and to order him to remedy any injury to a worker disadvantaged by the practice. Thus, it is empowered to order reinstatement and the payment of lost, or "back," wages where this will "effectuate the policies of the Act." Since any discharge which occurs during a strike protesting an unfair labor practice would not have occurred but for the original unfair labor practice, it is an injury arising from an unfair labor practice and will be remedied by reinstatement and back pay. The uniformity of NLRB practice in this respect makes it accurate to say that the employer has a much more limited right of discharge than he does in the ordinary case. Black Diamond S.S. Corp. v. NLRB, 94 F.2d 875 (2d Cir. 1938); Gregony, LanoN AND THE LAw 371-72 (2d rev. ed. with supp. 1961) ; Cox, The Right to Engage in Concerted Activities, 26 Ind. L.J. 319 (1951). Cf. NLRB v. Jones \& Laughlin Steel Corp., 301 U.S. 1, 45 (1937).

3. NLRB v. Thayer Co., 213 F.2d 748 (1st Cir.), cert. denied, 348 U.S. 883 (1954). Under section 2(3) of Taft-Hartley, 29 U.S.C. 152(3) (1958), the employment relation continues during the cessation of work accompanying an "economic" or "unfair labor practice" strike, so that the provisions of the act continue to apply to employer and employec activities during this time. The right to strike is one of the forms of collective activity protected by the act, Taft-Hartley Act $\$ 7,61$ Stat. 140 (1947), 29 U.S.C. $\$ 157$ (1958), amending Wagner Act $\S 7,49$ Stat. 452 (1935), and any attempt to coerce or punish workers engaging in such "protected" activity is itself an unfair labor practice, Taft-Hartley Act \$ 8(a) (1), 61 Stat. 140 (1947), 29 U.S.C. $§ 158$ (a) (1) (1958), justifying reinstatement or other remedy under $\S 10(\mathrm{c})$. Thus, where a strike is not provoked by an unfair labor practice, reinstatement may nonetheless be ordered to correct an improper dismissal, 213 F.2d at 752, although all dismissals will not be presumptively improper as they are in the unfair labor practice strike situation.

4. These policies are, inter alia, to "protect the right of employees to organize and bargain collectively" and to assure that labor organizations respect employers' rights 
reinstatement of all employees to rectify the unfair labor practice, notwithstanding the employees' tortious conduct ;" permit the employer to discharge some or all of the misbehaving strikers, regardless of the initial unfair labor practice, in order to vindicate the LMRA's policy requiring that labor organizations and their members respect employer's rights as well as the public order and safety ${ }^{6}$ or refuse to reinstate all employees who engaged in unlawful activities during the strike, although the employer has not formally dismissed them. ${ }^{7}$ Such strikes, invariably marked with employer bad faith and employee retaliation, may frequently involve dismissals ostensibly attributable to employee misconduct but primarily intended to weaken or destroy the collective movement in the plant. Any dismissal so intended, whether or not it occurred during a strike, would itself seem to be an unfair labor practice under section $8(a)(3)$ of the act, which proscribes discharges primarily intended to discourage or punish union membership and thus undermine legitimate collective activity. ${ }^{8}$ But the issue of whether such dismissals constitute new unfair labor practices has not been adequately considered in a strike misconduct situation. ${ }^{9}$

\section{Strike Misconduct Justifying Discharge}

Those tortious activities by striking employees which are sufficient to restore the employer's power of discharge during an unfair labor practice strike have not been clearly defined by the Board or the courts. ${ }^{10}$ NLRB v. Fansted

and do not jeopardize the public safety. Labor MIanagement Relations Act of 1947 (Taft-Hartley Act), § 101, 61 Stat. 136, 29 U.S.C.A. \$ 141 et seq.; National Labor Relations Act, \& 1 et seq.; 49 Stat. 449 (1935), as amended, 29 U.S.C.A. \$ 151 et seq. Cf. Mastro Plastics Corp. v. National Labor Relations Board, 350 U.S. 270 . . . (1956).

Local 833, UAW-AFL-CIO v. NLRB, 300 F.2d 699, 703 n.10 (D.C. Cir.), cert. denicd sib. nom. Kohler Co. v. Local 833, UAW-AFL-CIO, 370 U.S. 911 (1962).

5. Republic Steel Corp., 9 N.L.R.B. 219 (1938), enforced sib nom. Republic Steel Corp. v. NLRB, 107 F.2d 472 (3d Cir. 1939), modified on other grousds, 311 U.S. 7 (1940).

6. Kohler Co., 128 N.L.R.B. 1062 (1960).

7. H.N. Thayer Co., 115 N.L.R.B. 1591 (1956).

8. Section \&(a) (3), 61 Stat. 140 (1947), 29 U.S.C. § 158(a) (3) (1958). Cf. NLRB v. Jones \& Laughlin Steel Corp., 301 U.S. 1, 45-46 (1937).

9. The issue has been considered in the context of a so-called "economic strike" in which the contested issues are contract terms rather than statutorily defined "unfair" practices by the employer. In such a situation the right of the union to attempt to close the plant by its use of the economic weapon of a strike is matched by an employer right to keep his plant open, hire new workers on a permanent basis, and thus deprive striking workers of their jobs. The employer, however, may not go beyond this and discharge or refuse to re-employ at the termination of the strike workers not so replaced, nor may he fill those positions which are open by choosing among returning strikers in a discriminatory manner. Persons so discriminated against are entitled to reinstatement. NLRB v. Mfaclay Radio \& Tel. Co., 304 U.S. 333 (1938).

10. The employee's activity is said to be "unprotected" under $\$ 7$, so that employer interference with it is not within the prohibition of $\S 8(a)(1)$ and discharges because of it are justified even in the unfair labor practice strike situation. Unprotected activity includes participation in activity which would be a union unfair labor practice under $\$ 8(b)(1)(A), 61$ 
Metallurgical Corp. ${ }^{11}$ decided soon after the NLRA was passed, indicated that any act of employee misconduct during a strike was a per se bar to reinstatement. Having discharged all the strikers participating in a violent sit-down strike at the inception of the strike, Fansteel subsequently offered to rehire a number of them, but without recognition of their union. Because of the employer's strike-provoking refusal to bargain with the union and his coercive activities directed against it, the NLRB found that reinstatement of all employees was warranted, notwithstanding their unlawful activities in seizing and maintaining possession of the plant. ${ }^{12}$ Disturbed by the violence of this and other strikes of the era, the Supreme Court refused enforcement to the Board's order, holding that the "illegal" violence of the employees provided an "independent and adequate basis" for the discharges. ${ }^{13}$ While it is uncertain whether the misconduct worked to sever the employment relation, ${ }^{14}$ remove the employees from the protection of the act, ${ }^{15}$ or make Board reinstatement an abuse of discretion, ${ }^{10}$

Stat. 140 (1947), 29 U.S.C. $§ 158$ (b) (1) (A) (1958), as well as individual acts of misconduct such as verbal or physical abuse of non-strikers. Cox, supra note 2; Note, Strike Misconduct as Grounds for Denial of Reinstatement, 32 N.Y.U.L. REv. 839 (1957); GREGORY, op. cit. supra note 2, at 372-82.

11. 306 U.S. 240 (1939), affirming as modified 98 F.2d 375 (7th Cir. 1938).

12. Fansteel Metallurgical Corp., 5 N.L.R.B. 930 (1938).

13. NLRB v. Fansteel Metallurgical Corp., 306 U.S. 240, 255 (1939). This is the central thought of Fanstcel-that because one adequate basis of discharge exists, any other inadequate bases (i.e., discrimination) become irrelevant, since the striker is no longer "under the protection" of $\S 7$. See, e.g., NLRB v. Washington Aluminum Co, 370 U.S. 9 (1962). Strike violence is said to be particularly reprehensive because of the peaceful means of settling disputes made available by the act. "There is not a line in the statute to warrant the conclusion that it is any part of the policies of the Act to encourage employees to resort to force and violence ...." 306 U.S. at 257-58. "To justify such conduct because of the existence of a labor dispute or of an unfair labor practice would be to put a premitum on resort to force instead of legal remedies and to subvert the principle of law and order which lie at the foundations of society." Id. at 253. In his dissent, Mr. Justice Reed, with Mr. Justice Black concurring, aptly points out that reinstatement neither justifies nor encourages violence, but merely assures that the power to bar striking employees from protection under the act is kept out of the hands of employers guilty of strike provoking unfair labor practices. "Here both labor and management had erred grievously in their respective conduct. It cannot be said to be unreasonable to restore both to their former status," id. at 267, leaving peace officers to vindicate whatever public interest may have been aroused by the misconduct. See also Hart \& Prichard, The Fansteel Case: Employec Misconduct and the Remedial Powers of the National Labor Relations Board, 52 HARv. L. REv. 1275, 1302-29 (1939); NLRB v. Remington Rand, Inc., 94 F.2d 862 (2d Cir. 1938).

14. The Court suggests that $\S 2(3)$ of the act was not intended to countenance acts of "lawlessness," so that the acts themselves terminated the employees' rights. NLRB v. Fansteel Metallurgical Corp., 306 U.S. 240, 256 (1939).

15. Misconduct may also be considered as taking an employee outside the protection of $\$ 7$ of the act, so that he remains an employee under $\$ 2(3)$ only so long as the employer tolerates him as such. This differs from the theory outlined in note 14 supra only in that the employer is given the opportunity to make a general disavowal of intent to discharge which may work to stop him from subsequently terminating the employment relationship. NLRB v. Aladdin Industries, Inc., 125 F.2d 377 (7th Cir.), cert. denicd, 316 U.S. 706 (1942).

16. Finally, misconduct may be considered as suspending Board power to reinstate under 
the Court indicated in sweeping language that any activity which tends to detract from the peaceful settlement of labor disputes affords an employer the right to discharge any or all of the offending workers, regardless of his own previous conduct. ${ }^{17}$ The rehiring of some of the employees who engaged in the same violent activities was found to be a part of the usual employer prerogative to pick and choose those he would hire.

However, in spite of Fansteel, subsequent cases have recognized the possibility of abuse in automatically allowing an unfair labor practice employer to discharge strikers for such minor incidents as are always predictable adjuncts to a heated strike, and have refused to consider as serious enough to bar reinstatement certain types of misconduct occurring during an unfair labor practice strike. Thus, the Third Circuit, in Republic Stecl Corporation v. NLRB, ${ }^{18}$ read Fansteel as limited to situations involving a high degree of violence. ${ }^{10}$ Accordingly, the court ordered reinstatement of those strikers who had done no more than might be expected from the deep involvement of union members picketing an operating plant. Such minor disorders were found to be "protected activity" under section 7, which defines legitimate and thus protected collective activity generally. ${ }^{20}$ Subsequent decisions have recognized this exception to Fansteel, treating provoked misconduct or conduct ascribable to the "animal exuberance and mutual harassment" of the picket line-despite its

$\S 10$ (c) of the act. NLRB v. Fansteel Mfetallurgical Corp., 306 U.S. 240, 258 (1939). It should be clear that there is little real difference in effect among these different theories; each contemplates a complete suspension of Board authority to reinstate, given the finding that the misconduct took place.

17. For a strong criticism of the eloquent but over-general language which the Court's reactions engendered, and for suggestions for a more liberal though still act-oriented, handling of such situations, see Hart \& Prichard, supra note 13. The act-centered view of disqualification in "strike misconduct" remains the legacy of Fansteel. See NLRB v. Washington Aluminum Co., 370 U.S. 9 (1962) ; NLRB v. Insurance Agents' Int'l Union, 361 U.S. 477,494 (1960).

18. 107 F.2d 472 (3d Cir. 1939), modified on other grounds, 311 U.S. 7 (1940).

19. [S]ome disorder is unfortunately quite usual in any extensive or long drainn out strike. A strike is essentially a battle waged with economic weapons. Engaged in it are human beings whose feelings are stirred to the depths. Rising passions call forth hot words.... The transformation from economic to physical combat ... is difficult to prevent even when cool heads direct the fight. Violence of this nature, however much it is to be regretted, must have been in the contemplation of the Congress when it provided in Section 13 of the Act, 29 U.S.C.A. \& 163, that nothing therein should be construed so as to interfere with or impede or diminish in any way the right to strike.... [I]t was not intended by the Act that minor disorders of this nature should deprive a striker of the possibility of reinstatement.

Republic Steel Corp. v. NLRB, stpra note 18, at 479. Faustecl and Republic are not infrequently cited in tandem. E.g.j NLRB v. Wallick, 198 F.2d 477, 484 (3d Cir. 1952). Sce also NLRB v. Elkland Leather Co., 114 F.2d 221 (3d Cir.), cert. denied, 311 U.S. 705 (1940). Cf. NLRB v. Stackpole Carbon Co., 105 F.2d 167 (3d Cir. 1939); Mrilk Wagon Drivers Union v. Meadowmoor Dairies, Inc., 312 U.S. 287, 293 (1941).

20. See notes 3 and 10 supra. 
unquestioned character as misconduct-as protected activity, not intended by Congress to work a forfeiture of employee rights under the act. ${ }^{\mathbf{2 1}}$

The Taft-Hartley amendments added to section 10 (c) a proviso which appears to have been designed to delineate some conduct for which an employer might effectively discharge his employees, by providing that the Board is without power to reinstate employees who are discharged "for cause."22 The discussion of union violence and the Fansteel case in Congress indicates that "cause" was meant to include many acts of strike misconduct, ${ }^{23}$ such as participation in those activities proscribed in section $8($ b) as union unfair labor practices and in activities that violate federal and perhaps state penal statutes. Since the proviso operates as a limitation on the Board's jurisdiction, it would seem that the statute requires independent consideration of the meaning of cause before permitting the Board to engage in a discretionary balancing process to determine whether or not reinstatement would effectuate the policies of the act. But the few cases dealing with the "for cause" proviso in a strike misconduct situation ${ }^{24}$ have not interpreted it to include any fixed category of acts which justify discharge in all cases or to enlarge the employer's right to discharge.

21. The analysis is expressed in such terms as "protected-unprotected," "seriousminor," or "intentional violence-spontaneous exuberance." See NLRB v. Pucrto Rico Rayon Mills, Inc., 293 F.2d 941 (1st Cir. 1961) ; NLRB v. Wichita TV Corp., 277 F.2d 579 (10th Cir.), cert. denied, 364 U.S. 871 (1960) ; NLRB v. Cambria Clay Products Co., 229 F.2d 433 (6th Cir. 1955) ; Victor Products Corp. v. NLRB, 208 F.2d 834 (D.C. Cir. 1953) ; NLRB v. Wallick, 198 F.2d 477 (3rd Cir. 1952) ; NLRB v. Kelco Co., 178 F.2d 578 (4th Cir. 1944). See also NLRB v. Washington Aluminum Co., 370 U.S. 9 (1962).

22. No order of the Board shall require the reinstatement of any individual as an cmployee who has been suspended or discharged, or the payment to him of any back paty, if such individual was suspended or discharged for cause.

Taft-Hartley Act $\$ 10$ (c), 61 Stat. 147 (1947), 29 U.S.C. \$ 160 (c) (1958).

See Cox, Some Aspects of the Labor Management Relations Act, 1947, 61 Havv. L. Rev. 1, 20-22 (1947) ; 1 U.S. National Labor Relations BoARD, Legislative Fitstory of ti1E Labor-Management Relations AcT, 1947, 333-34, 537, 542-44, 558-59, 563 (1948) [hereinafter cited as LEGIS. HIST.]. The "for cause" proviso appears to apply equally to all discharges, whether for strike misconduct or inefficient work. Cf. notes 63-64 infra and accompanying text.

23. Undesirable concerted activities are not to have any protection under the act, and to the extent that the Board in the past has accorded protection to such activitics, the conference agreement makes such protection no longer possible. Persons who engage in or support unfair labor practices will not enjoy immunity under the act.

1 LEGIS. HIst. 543-44 (statement of House conference managers). See also 1 LEGrs. Hist. 318 (report of House Committee on Education and Labor), 434 (report of Senate Committec on Labor and Public Welfare), 882 (speech by Rep. Hartley), 905 (speech by Rep. Landis), 912 (speech by Rep. Lesinski), 917 (veto message by President Truman) ; 2 LEGis. HIst. 1555 (speech by Sen. Morse), 1572 (speech by Sen. Murray), 1593 (speech by Sen. Pepper). Cf. \$ 1, 61 Stat. 137 (1947), 29 U.S.C. $\$ 151$ (1958); 1 LEGrs. Hrst. 69, 101, 176, 228.

24. In addition to Local 833, UAW-AFL-CIO v. NLRB, 300 F.2d 699 (D.C. Cir.), cert. denied sub nom. Kohler Co. v. Local 833, UAW-AFL-CIO, 370 U.S. 911 (1962), and NLRB v. Thayer Co., 213 F.2d 748 (1st Cir.), cert. denied, 348 U.S. 833 (1954), the two cases herein discussed, the Supreme Court has twice discussed the "for cause" proviso in strike contexts, but only to the extent of finding that a given activity is or is not "cause" 
In fact, the two most extensive attempts to evaluate the meaning of the proviso have apparently given greater stress to the policy of protecting the rights of employees to engage in collective activity and thus to an unrestricted discretionary approach than to protection of the right of employer redress against strike violence emphasized in Fansteel.

In the first of these cases, $N L R B$ v. Thayer Co., ${ }^{20}$ the Court of Appeals for the First Circuit was asked to enforce a reinstatement order for numerous employees who, during the course of an unfair labor practice strike, had participated in "coercive" activities which the Board had nonetheless characterized as protected, in accord with the Republic analysis. ${ }^{20}$ The court rejected this "protected-unprotected" dichotomy as unnecessary and inappropriate where coercive strike activities were involved, and stated that "the actual questions in this case are whether under the circunstances the strike conduct was cause for discharge, and if not whether reinstatement would effectuate the policies of the Act."27 Although the court thus recognized the two questions posed by the addition of the proviso to the act, it characterized cause as depending upon the context of the given case rather than specific acts of misconduct per $s e$, and failed to enunciate any criteria relevant to a determination of "cause." Reluctantly accepting the remand, the Board recanted its original finding, holding that reinstatement of men who had engaged in coercive activities could not effectuate the policies of the act. The NLRB totally ignored the first question put to it-that of "cause"-and in dealing with the second seemed merely to reaffirm its original "protected-unprotected" analysis, transferring these men to the latter category on the basis of the court-imposed finding that misconduct can never be protected activity. ${ }^{29}$ Given the apparent requirement of the statute that the existence of the employer's discharge power be respected by the Board and courts, the First Circuit's attempt at a narrow definition of this power, with its boundaries to be determined in each case by the Board, seems a compromise weighted as much towards discretion as possible. ${ }^{30}$ However, as the disposition

within the meaning of the statute. NLRB v. Local 1229, International Bhd. of Electrial Workers, 346 U.S. 464 (1953), and NLRB v. Washington Aluminum Co., 370 U.S. 9 (1962).

25. Supra note 24.

26. The Board found that none of the conduct it dealt with "involved actual restraint, violence, or coercion, or conduct which exceeded the animal exuberance and mutual harassment characteristics of such strike situations." H. N. Thayer Co., 99 N.L.R.B. 1122, 1133 (1952).

27. 213 F.2d at 754. (Emphasis added.)

28. $213 \mathrm{~F} .2 \mathrm{~d}$ at 753 n.6 and italicized language quoted in text at note 27 sipro. Implicit in the dual question asked by the court, however, is the notion that Board authority ends where "cause" begins.

29. H. N. Thayer Co., 115 N.L.R.B. 1591, 1596 (1956).

30. In order for both questions to be meaningful when coercive strike activity occurs, it would seem that there must be situations in which non-cause coercion does not automatically divest strikers of reinstatement rights. That is, the court's opinion can be read as establishing an intermediate area, in which knowledge of the employee's acts in racus would not be sufficient to establish the proper disposition of the reinstatement issue See NLRB v. 
on remand and subsequent proceedings demonstrate, the Board has been unwilling to make use of this addition to its discretion. ${ }^{31}$

The recent action of the Court of Appeals for the District of Columbia, in reviewing the NLRB's suggested remedy ${ }^{33}$ for the unfair labor practices involved in the notorious Kohler strike, ${ }^{34}$ has given new emphasis to the Thayer treatment of the reinstatement issue. The Board had denied reinstatement to the ninety workers Kohler had specifically discharged for misconduct. Some of the ninety had not participated to any greater degree than 1,700 other strikers in the frequent acts of violence that scarred this long and bitter strike against a determinedly anti-union employer. ${ }^{35}$ The NLRB found that their presence during mass picketing or other activity where weight of numbers had contributed to coercive effect was no less serious than active violence. ${ }^{80}$ Bare presence at

Puerto Rico Rayon Mills, Inc., 293 F.2d 941 (1st Cir. 1961) ; NLRB v. Efco Mfg., Inc, 227 F.2d 675 (1st Cir. 1955), cert. denied, 350 U.S. 1007 (1956). But see NLRB v. Wallick, 198 F.2d 477 (3rd Cir. 1952).

31. Kohler Co., 128 N.L.R.B. 1062, 1193-94 (1960).

32. Local 833, UAW-AFL-CIO v. NLRB, 300 F.2d 699 (D.C. Cir.), ccrt. denicd sub nom. Kohler Co. v. Local 833, UAW-AFL-CIO, 370 U.S. 911 (1962).

33. Kohler Co., 128 N.L.R.B. 1062 (1960). That portion of the NLRB decision which was summarily enforced by the D.C. Circuit, involving reinstatement of the workers not explicitly discharged for their strike activities and determination that the Kohler Company had been guilty of prolonging the strike by its unfair labor practices, is not herein discussed. Moreover, the Board determination that the strike was at its inception an economic strike is not of interest here except as it reflects on the reinstatement of those "permanently replaced" during the interim preceding its mutation into an "unfair labor practice" strike. Sce note 9 supra. Since this was the period in which the plant was effectively closed by mass picketing, few were so affected.

34. A summary of the facts appears at 128 N.L.R.B. 1145-1240. See also Select Committee on Improper Activities in the Labor or Management Field (McClellan Committec), Final Report, S. REP. No. 1139, 86th Cong., 2d Sess. pt. 2, 141-283 (1960). [Hereinufter cited as McClellan Rep.] For more partisan views, compare Petro, The Kohler Strure-Union Violence and Adninistratrve Law (1961) with Kennedy, Tae ENEMy Wituin ch. 13 (1960). The strike, which gained nationwide attention, cost the union almost $\$ 10,000,000$ over its six-year duration. MicClellan Rep. at 264. The McClellan Committee majority characterized it as "a classic example of labor-management relations at its worst-where the community, the worker, and management all suffer and none gain." Id. at 278.

35. The strike involved company arsenals and brutal assaults on non-strikers, employer unfair labor practices and mass picketing. Of an estimated 1800 workers who participated in the mass picketing, the Kohler Company selected forty-four for discharge; some of those discharged had engaged in acts beyond mere presence on the line, others were simply "there," and thirteen were members of the strike committee which directed the picketing activities. The discharge of additional strikers who had either been present at or taken part in other activities-picketing homes of non-strikers, violent picketing of the Kohler employment office, and other miscellaneous misconduct-brought the total number of discharges to ninety. Kohler sought to supply the NLRB with a list of over 500 incidents which it attributed to union violence and gave wide publicity to this violence in an attempt to win consumer ap. proval and vindicate its near-complete refusal to bargain. The union retaliated in kind, with a broad attempt to establish a nation-wide boycott of Kohler goods. See sources cited noto 34 supra.

36. 128 N.L.R.B. at 1103-08. The denial of reinstatement included among those to whom it applied the thirty-five discharged strikers whom the Trial Examiner had recommended for 
such activities was thus held to strip employees of all protection under the act. ${ }^{37}$ The court, however, explicitly rejected as inconsistent with the Board's duties any such per se rule of disqualification for strike misconduct viewed out of the context of employer provocations and unfair labor practices, and remanded the reinstatement issue for reconsideration in terms of the two questions asked by the Thayer court. ${ }^{38}$ In so doing in a case in which reinstatement had initially been denied by the Board, the court stressed the affirmative, discretionary nature of the decision expected of the Board that had been neglected on the Thayer remand.

In discussing the first question posed by Thayer, the court did not elaborate on "for cause" as a statutory bar to reinstatement, but merely stated that the issue was not raised before the Board and, since it is a question peculiarly directed to it, could not be treated upon appeal..$^{30}$ The court did, however, suggest some criteria for determining when 10 (c) precludes reinstatement of employees discharged "for cause," such as "the employer's unfair labor practices, each employee's job history, and the relationship between the acts of misconduct and fitness for continued service." 40 This summary treatment of the proviso seems

reinstatement. Id. at 1192-1240. It should be noted that the question of mions unfair labor practices was never brought before the Board, although there is little doubt that many of the activities were in violation of $\S 8$ (b) (1) (A), 61 Stat. 141 (1947), 29 U.S.C. \& 158(b) (1) (A). Soon after the strike began, Kohler went to the Wisconsin Employment Relations Board to get an injunction against the mass picketing and other union activities. The union challenged this proceeding with a preemption theory eventually rejected by the Supreme Court. The Court stated that the violent activities would have been unfair labor practices under $\S 8(b)$ (1) (A) of Taft-Hartley but held that the states had not lost their police power prerogative of dealing with violence. UAW v. Wisconsin Employment Relations Bd, 351 U.S. 266, 275 (1956). Kohler probably did not complain directly to the NLRB for fear of prejudicing the state action and resultant injunction, which could be obtained more promptly than the corresponding NLRB order.

37. The conclusion, reached by a bare majority, seems justified, given the rules the NLRB has adopted. Presence is the essence of the evil of mass picketing.

38. $300 \mathrm{~F} .2 \mathrm{~d}$ at 702-04. The court did not consider questions of condonation (see note 45 infra and accompanying text) or presence-as-unprotected-activity, apparently assuming that such considerations would be better dealt with as relevant to a decision under the Thayer doctrine than as separate "affirmative defenses." It ordered the Board to reconsider, in the light of Kohler's twenty-year history of anti-union activities (begun with a well-remembered strike in 1934, in which forty-nine unionists were injured or killed by gunfire, and styled "twenty years of labor peace" by Kohler-MicClellan Rep. 145-53), its findings that the strike had not been an unfair labor practice strike from its inception, thus opening further possibilities of reinstatement. See note 33 supra. A dissent to the court's opinion questioned the relevance of Thayer to a case in which union misconduct was so blatant, characterizing Kohler's unfair labor practices as "feeble efforts ... to protect itself against open warfare. ...300 F.2d at 711. This seems to be little more, however, than a disagreement about interpretation of the facts of the dispute. Cf. note 80 infro.

39. 300 F.2d at 705. It is not clear, however, that the Board failed to consider "cause." Some language suggests, without explicit reference to $\S 10(c)$, that it thought "sufficient cause" was present. 128 N.L.R.B. at 1105 . Cf. note 76 infra.

40. 300 F.2d at 705. (Footnotes omitted.) Fitness for continued service seems a particularly appropriate criterion and has been referred to on other occasions. NLRB v. Pucrto 
questionable. Because of relative institutional competencies, some questions of law admittedly are within the Board's ambit of discretion. ${ }^{41}$ But the proper interpretation of a provision which describes the outer reaches of the Board's power would not seem to be one of these. ${ }^{42}$ Furthermore, the criteria briefly enumerated by the court for determining whether a discharge was for cause are among those used for balancing employer and employee interests-the second question posed by the Thayer court. In fact, the cases cited in elaboration of the discussion of the "for cause" factors are all determinations not of whether misconduct constitutes "cause" but whether misconduct justifies a refusal to reinstate under a balancing test, albeit under the somewhat different formulation of this test which was espoused in the Republic decision. ${ }^{43}$

Although Thayer and Kohler formally adhered to a proviso that apparently presupposes two separate tests for determining the validity of a discharge, the failure to give substantive content to the first test in Thayer and the D.C. Circuit's treatment of the proviso in Kohler indicate that, in effect, the only operative test is the discretionary one of balancing. This balancing test explicitly recognizes the tacit consideration underlying the apparent and misleading justification of coercion present in such decisions as Republic. Thus, these cases, with their emphasis on arriving at a result consistent with the conflicting policies of the act through a careful weighting of the interests of the employer and the employee, seem to have minimized the effect of the "for cause" proviso as an independent consideration in deciding whether to reinstate discharged employees in any particular case.

\section{Discriminatory Discharges Justifying Reinstatement}

Insofar as Kohler commands the NLRB to use discretion comprehending the entire context of events in deciding whether an employee has so acted while on strike as to give his employer the right to discharge him for his misconduct, it is a salutary decision, enhancing Board discretion in an area where per se rules seem inappropriate. ${ }^{44}$ But both the court and the Board appear to have

Rico Rayon Milis, Inc., 293 F.2d 941 (1st Cir. 1961) ; NLRB v. Wytheville Knitting Mills, 175 F.2d 238 (3d Cir. 1949) (other employees legitimately declined to work with dischargees) ; Note, Strike Misconduct as Grounds for Denial of Reinstatememt, 32 N.Y.U. L. Rev. 839, 843, 847-48 (1957) and arbitration cases there cited; dissent to H. N. Thaycr Co., 115 N.L.R.B. 1591, 1604 (1956) (decision on remand) ; cf. text accompanying note 28 stipra.

41. O'Leary v. Brown-Pacific-Maxon, Inc., 340 U.S. 504, 507-08 (1951); cf. SEC v. Chenery Corp., 318 U.S. 80, 87-88 (1943).

42. 4 Davis, Administrative Law Treattse $\$ 30.09$ (1958).

43. $300 \mathrm{~F} .2 \mathrm{~d}$ at $705 \mathrm{nn} .21 \& 22$; see notes $18-21$ supra and accompanying text.

44. Thayer and Kohler are themselves good examples of this. See also Mastro Plastics Corp. v. NLRB, 350 U.S. 270, 280-88 (1956) ; speech by NLRB Chairman McCulloch, The NLRB in Action, 49 LAB. ReL. Rep. (49 L.R.R.M.) 640, 643 (1962) ; Advisory Pand on Labor-Management Relations Law, Report on the Organization and Proccdures of the NLRB to the Senate Committee on Labor and Public Welfare, SEN. Doc. No. 81, 86th Cong., $2 \mathrm{~d}$ Sess. 5 (1960). 
overlooked ${ }^{45}$ the possibility that Kohler's dismissal of only ninety of the 1,800 workers who engaged in various acts of misconduct, including all the important leaders of the union, ${ }^{46}$ itself constituted an unfair labor practice under section 8(a) (3), which proscribes as "discriminatory" all discharges that are intended to discriminate among employees so as "to encourage or discourage membership in any labor organization." 47 In fact, the Kolller court's reiteration of the two questions posed by the Thayer court makes it plain that it was only concerned with the existence of "cause," and not with reliance upon it.48 Although the Board and courts have extensively considered discriminatory discharges where an employee is allegedly discharged for incompetence or misbehavior while on the job, ${ }^{49}$ this lack of regard for the policy of section 8 (a) (3) is typical of judicial and administrative response to employer discharges in a strike misconduct situation-notwithstanding that in some of the strike misconduct cases, the employer's rehiring of some of the strikers and refusal to rehire others indicates a pattern from which discrimination for the purpose of frustrating collective activity may be inferred.50

Where an employee is discharged for strike misconduct, the question of employer motive has been narrowly and formalistically considered, if at all. Without explicitly relating the issue to section 8 (a)(3) in terms of a new unfair labor practice, the Board has developed technical doctrines of "condona-

45. The Trial Examiner had, in fact, given limited attention to a union contention that Kohler's extensive files on the strike, used to justify the discharges, formed no more than a pretext for the company's calculated attempt to destroy the union movement. 128 N.L.RB. at 1191-92. The Board, however, dismissed the issue in a one sentence footnote. Id. at 1102 n.63.

46. See notes 34-36 supra and accompanying text.

47. Taft-Hartley Act § 8(a) (3), 61 Stat. 140 (1947), 29 U.S.C. § 158(a) (3) (1958).

48. $300 \mathrm{~F} .2 \mathrm{~d}$ at 702-04. See notes $27,28 \& 38$ sipra and $80 \mathrm{infra}$.

49. An extreme example of this is Wyman-Gordon Co., 62 N.L.R.B. 561 (1945), modified sub nom. Wyman-Gordon Co. v. NLRB, 153 F.2d 480 (7th Cir. 1946). Discharges of union organizers occurred after their activities had led to a reduced production rate at a plant whose production was absolutely vital for the war effort. The Board ordered reinstatement on the ground that the discharges were discriminatory, inferring such discrimination from other anti-union practices of the employer and from a finding that the activities urged as grounds for dismissal were engaged in by other discharged employees. The 7th Circuit refused enforcement, because of the paucity of evidence and the obvious importance of preventing interference with the war effort. This case, perhaps because of the "war effort" factor, attracted the particular censure of the sponsors of the Taft-Hartley Act, who trented it as examplar of usual board practice. 1 LeGrs. Hrst. 333, 559. See also Frosty 1 forn 1 feats, Inc. v. NLRB, 296 F.2d 617 (5th Cir. 1961); NLRB v. Vail Mffg. Co., 158 F.2d 664 (7th Cir.), cert. denied, 331 U.S. 835 (1947) ; NLRB v. Arcade-Sunshine Co., 118 F.2d 49 (D.C. Cir.), cert. denied, 313 U.S. 567 (1941).

50. In NLRB v. Mackay Radio \& Tel. Co., 304 U.S. 333 (1938), the issue was raised in connection with an economic strike and resolved in favor of the applicability of \& 8(a) (3). In Mackay, the failure to rehire five strikers at the end of an economic strilke because their jobs had been permanently filled by non-strikers was, in itself, unexceptional; however, when it appeared that the five to be let go were chosen on the basis of their union activity, a reinstatement order was properly enforced. The analogy to Alackay has never been drawn in the unfair labor practice strike situation, however. See note 9 sipra. 
tion" and "reliance" for dealing with the discharge of striking employeesdoctrines which appear to be concerned with the motive of discharge but which are heavily weighted toward the employer's own expression of his reasons for discharge. Reinstatement will be ordered where the employer has condoned the misconduct of his workers. ${ }^{51}$ Proof of condonation requires an expression by the employer to a particular worker or group of workers to the effect that he has waived or forgiven the misconduct..$^{22}$ If he has made no such indication, the fact that the employer fails to discharge or rehires others whom he knows to have taken part in the same activity is not condonation of it, but a legitimate exercise of his power to choose those he wishes to employ. ${ }^{50}$ The inability of the condonation doctrine to deal with discriminatory situations seems well demonstrated by the Kohler decision. In a dissent, one member of the Board expressed a conviction that the company was using the misconduct as a cloak for its intent to "oust the [u]nion." 54 Yet the same member cast the decisive vote in the Board determination that "condonation" was not present. 55

Reinstatement may also be ordered if the Board determines that there was no reliance on the misconduct. If the employer fails to state his reason for discharge, or states one other than the strike misconduct, the Board may refuse to recognize his later allegation that he actually did rely on the misconduct. Thus, investigations into the genuineness of the "reliance" upon the grounds urged for discharge have tended to stop with the finding that the employer has never formally indicated non-reliance-a sort of personal con-

51. Note, Strike Misconduct as Grounds for Denial of Reinstatement, 32 N.Y.U.L. REv. 839 (1957).

52. E.g., NLRB v. E.A. Laboratories, Inc., 188 F.2d 885 (2d Cir.), ccrt. denicd, 342 U.S. 871 (1951) ; NLRB v. Aladdin Industries, Inc., 125 F.2d 377 (7th Cir.), cert. dchicd, 316 U.S. 706 (1942). The requirements are made more stringent by the rule that:

Where misconduct is clear, condonation may not be lightly presumed from mere silence or equivocal statements, but must clearly appear from some positive act by an employer indicating forgiveness and an intention of treating the guilty employecs as if their misconduct had not occurred.

NLRB v. Marshall Car Wheel \& Foundry Co., 218 F.2d 409, 414 (5th Cir. 1955). This rule apparently was adopted by the Board in Kohler Co., 128 N.L.R.B. 1062, 1105 (1960). Compare this with the Fifth Circuit's similar approach to "assembly line" discharges, note 65 infra. Cf. text accompanying notes 70-78 infra.

53. This "right" to pick and choose was first referred to in NLRB v. Fansted Metallurgical Corp., 306 U.S. 240, 259 (1939). That case involved a fact situation in which discrimination could have been found but for the fact that the chief union adherents "chose" themselves by refusing to scab. Fansteel Metallurgical Corp., 5 N.L.R.B. 930, 945, 949 (1938). See also NLRB v. Clearfield Cheese Co., 213 F.2d 70, 75 (3d Cir. 1954); NLRB v. Dorsey Trailers, Inc., 179 F.2d 589 (5th Cir. 1950) ; Brief for NLRB, p. 120, Local 833, UAW-AFL-CIO v. NLRB, 300 F.2d 699 (D.C. Cir. 1962); Cox, stipra note 2; Note, Strike Misconduct as Grounds for Denial of Reinstatement, 32 N.Y.U.L. REv. 839 (1957); notes 58-62 infra and accompanying text.

54. Kohler Co., 128 N.L.R.B. 1062, 1137 (1960).

55. Id. at 1102-08. 
donation. ${ }^{56}$ Although these doctrines may be viewed as an inquiry into the reason for the discharge, their limited scope and technical requirements render them ineffective as criteria for determining whether the discharge is discriminatory and thus whether the discharge is itself a new unfair labor practice for which the remedy of reinstatement, regardless of misconduct, seems varranted. .7

Criteria to determine employer intent have long been used in analogous cases of discharges of assembly line employees ${ }^{\text {ts }}$ and of refusals to rehire economic strikers. Thus, after an economic strike, an employer, as a matter of right, may refuse to rehire any employees he wishes but he may not do so with an intent to discourage union membership or activity in his plant..$^{50}$ The policy underlying reinstatement of assembly line workers or economic strikers discharged for their union support activities-protection and fostering of collective activity-would equally seem to apply to misbehaving strikers discharged for similar reasons. But unconsidered language in the Fansteel opinion, implying that once employees are found to have committed an act of misconduct, their employer possesses the right to hire or fire them on any basis, appears to have furnished the basis for treating the strike misconduct situation differently..$^{\circ 0}$ The emplasis upon this right to "pick and choose" among striking employees, stated without the qualification which the analogous holdings of other cases and $S(a)(3)$ would seem to require, has inhibited realistic consideration of whether strike misconduct discharges are themselves unfair labor practices. ${ }^{01}$ In addition, this judicial insensitivity to the possibility of employer discrimination may be attributable to an understandable reluctance on the part of courts to inquire into the question of motive, a difficult inquiry in itself, in the context of a heated strike situation. ${ }^{62}$

56. NLRB v. Anchor Rome Mills, Inc., 228 F.2d 775 (5th Cir. 1956) ; NLRB v. Clearfield Cheese Co., 213 F.2d 70 (3rd Cir. 1954) ; NLRB v. Wallick, 198 F.2d 477 (3d Cir. 1952).

57. Compare Magnolia Petroleum Co. v. NLRB, 200 F.2d 148 (5th Cir. 1952) and NLRB v. Electric City Dyeing Co., 178 F.2d 980 (3rd Cir. 1950) ("condonation" found on a broad basis where employers discharged from assembly line), with Wilson \& Co. v. NLRB, 120 F.2d 913, 923-34 (7th Cir. 1941) and NLRB v. Clearfield Cheese Co., 213 F.2d 70, 75 (3rd Cir. 1954) (condonation not found in strike misconduct situations beause of formal employer acts).

58. For recent examples, note the Trial Examiner's reports in Walton Mffg. Co., 124 N.L.R.B. 1331, 1340-75 (1959), and Frosty Morn Meats, Inc, 127 N.L.R.B. 1586, 1594 (1960). Cf. cases cited note 57 supra.

59. NLRB v. Mackay Radio \& Tel. Co., 304 U.S. 333 (1938).

60. See NLRB v. Fansteel Metallurgical Corp., 306 U.S. 240, 254, 259 (1939); note 13 supra.

61. See cases cited note 53 supra. It should be noted, however, that, contrary to the apparent meaning of the words the Court used, the employer did no"choosing" in the Fansteel situation. He discharged all and hired those who applied to come back-men who were, of course, the weakest of the union adherents. Fansteel Mretallurgical Corp., 5 N.L.R.B. 930, 945, 949 (1938).

62. It should be kept in mind that it is economically somewhat easier for employers to dismiss a few extra men from a picket line in order to conceal his improper motive than it is for him to dismiss "decoys" from an operating assembly line along with union leaders 
Although discrimination may be present in the discharge of a delinquent striker, as in the discharge of an inefficient worker, the fact that misconduct is more public than inefficiency may seem to make the issue of motive less important. When a "cause" which clearly affects the employer's interests plainly exists, it might seem that motive speaks for itself. But this argument would also seem to be relevant to those cases in which the existence of "cause" for discharge from the assembly line is similarly clear. ${ }^{63}$ In fact, the discussion of the "for cause" proviso in Congress indicates that many of its supporters desired to inhibit the inference of improper motive where an independent reason for discharge of non-striking employees was established. ${ }^{64}$ The Court of $\mathrm{Ap}$ peals for the Fifth Circuit, relying upon a restrictive interpretation of the reinstatement authority of the NLRB and upon these legislative statements, has established a rule in non-strike dismissal cases giving special weight to the employer's testimony that he has relied upon "cause" when that cause is found to have existed. It has thus frequently refused enforcement of reinstatement orders in such situations, in spite of the presence in the record of ample testimony upon which the Board might have relied in finding that the employer's motive for discharge was discriminatory, regardless of the existence of "cause" of As this court recently stated :

of whom he wishes to be rid. The difficulty of proof and need for thoroughness in factfinding efforts are correspondingly greater.

63. I.e., insubordination, inefficiency, violation of important plant rules.

64. Thus, the House Report is particularly concerned with cases like Wyman-Gordon Co., 62 N.L.R.B. 561 (1945), modified sub nom. Wyman-Gordon Co. v. NLRB, 153 F.2d 480 (7th Cir. 1946), in its discussion of $\S 10$ (c): "The Board may not 'infer' an improper motive when the evidence shows canse for discipline or discharge." 1 LEGrs. Hrst. 333-34. (Emphasis added.) The original wording of the House Bill reflects the changed emphasis they desired in an altered burden of proof which did not survive the Conference Report. "No order of the Board shall require the reinstatement of any individual ... unless the weight of the evidence shows that such individual was not suspended or discharged for cause." Id. at 69. (Emphasis added.) Reference to Wyman-Gordon in the Conference Report and textual discussion of the "for cause" proviso, moreover, makes it appear that this effect was still anticipated for the "assembly line" situations to which $\S 10(\mathrm{c})$ was the only applicable language. Id. at 559. Senator Taft, on the other hand, in presenting the Conference Report to the Senate, stated that he felt the emphasis had not been changed and that the question of motive was "[i]n every case ... a question of fact for the Board to determine." 2 LEGIS. Hist. 1593. This interpretation was also urged as the correct one by Professor Cox, who found the real danger in the potential encouragement of discrimination by those who believed that the House interpretation would be put upon it. Cox, Some Aspects of the Labor Management Relations Act, 1947, I, 61 HARv. L. REv. 1, 20 (1947). Senator Taft's remarks have been cited by favorably disposed courts, both in "assembly line" discharge situations to which they were directed, NLRB v. Dixie Shirt Co., 176 F.2d 969, 974 (4th Cir. 1949); and in "strike misconduct" situations to which they were not, Local 833, UAW-AFL-CIO v. NLRB, 300 F.2d 699, 705 (D.C. Cir. 1962), cert. denied sub nom. Kohler Co. v. Local 833, UAW-AFL-CIO, 370 U.S. 911 (1962).

65. NLRB v. Walton Mfg. Co., 286 F.2d 16, 25 (5th Cir. 1961) rev'd, 369 U.S. 404 (1962). In addition to the Fifth Circuit cases cited in these two opinions, see NLRB v. Fontainbleau Hotel, 49 L.R.R.M. 2890 (5th Cir. 1962); Schwob Mfg. Co. v. NLRB, 49 L.R.R.M. 2360 (5th Cir. 1962). Compare NLRB v. Croscill Curtain Co., 49 L.R.R.M. 2317 
In each such case such membership may have been the cause [of discharge or lay-off], for the union was not welcomed by the persons having authority to discharge and employ. If no other reason is apparent, union membership may logically be inferred. Even though the discharger disavows it under oath, if he can assign $n 0$ other credible motive or cause, he need not be believed. But it remains true that the discharger knows the real cause of discharge, it is a fact to which he may swear. If he says it was not union membership or activity, but something else which in fact cxisted as a ground, his oath cannot be disregarded because of suspicion that he may be lying. There must be impeachment of him, or substantial contradiction, or if circumstances raise doubts, they must be inconsistent with the positive sworn evidence on the exact point. ${ }^{.0}$

Thus, if the employer can prove that a cause was given and alleges that he relied on it, the necessarily circumstantial evidence which the Board must often use will frequently be found wanting, however convincing it might seem as an interpretation of the record as a whole. ${ }^{67}$ The effect of this rule has been to create a stricter standard of review for reinstatement orders than for cease and desist orders $;^{68}$ not infrequently the court enforces cease and desist orders

(4th Cir. 1961), in which an order was denied because of scant "cause" (complaint of antiunion worker placed opposite to dischargee on morning of discharge), will NLRB v. Bendix Corp., 49 L.R.R.M. 2675 (6th Cir. 1962), in which order was enforced in spile of "cause" (breaking equipment, record of carelessness). For a more recent treatment explicitly" in terms of $\S 10$ (c), see NLRB v. Atlanta Coca-Cola Bottling Co., 293 F.2d 300 (5th Cir. 1961). It should be remembered that the 5th Circuit particularly, and the 4th Circuit to a lesser extent, sit in areas where unions have been notoriously unsuccessful in organizing because of employer opposition.

66. Quoted in NLRB v. Walton Mfg. Co., supra note 65, at 25. (Emphasis added.)

67. Although this discussion is not meant to imply that Board orders must alueays be enforced, compare the facts of Miiller Elec. Mfg. Co. v. NLRB, 265 F.2d 225 (7th Cir. 1959) (denying enforcement for worker admitted to be obnoxious and hard to get along with and discharged previous to any other indication of anti-union animus) atith those of Frosty $\mathbf{M}$ (orn Meats, Inc. v. NLRB, 296 F.2d 617 (5th Cir. 1961) (strongly anti-union employer expressed intent to fire union organizer five days before his discharge "for" disobedience). See also Sunshine Biscuits, Inc. v. NLRB, 274 F.2d 738 (7th Cir. 1960).

68. In $N L R B$ v. Tex-O-Kan Flour Mfills Co., 122 F.2d 433 (5th Cir. 1941), dealing with a similar situation under the Wagner Act, the court had noted that unlike cease and desist orders, which are prospective in application, orders for reinstatement and bacls pay may have the effect of a "penalty" on the employer, requiring payment of substantial amounts of money. It therefore stated its greater willingness to enforce cease and desist orders. The court apparently did not consider the "penal effect" of an uncorrected discriminatory discharge on the employee discharged, nor early court discussion which foreclosed treatment of the reinstatement remedy as a quasi-penalty. Compare Phelps Dodge Corp. v. NLRB, 313 U.S. 177 (1941), Republic Steel Corp. v. NLRB, 311 U.S. 7 (1940), and NLRB v. Fansteel Metallurgical Corp., 306 U.S. 240, 256-58 (1939) with NLRB v. Carlisle Lumber Co., 99 F.2d 533 (9th Cir. 1938). A vigorous supporter of Taft-Hartley in the House did suggest that disqualification for unprotected acts was intended as a penalty against the $\mathrm{cm}$ ployee (Remarks of Rep. Landis, 1 LeGrs. Hrst. 905), but the reinstatement power has long been characterized, in terms of employer unfair labor practices, as limited in its appliation to a remedial restoration of the status quo. NLRB v. Remington Rand, Inc, 94 F.2d 862, 872 (2d Cir. 1938). As the date of Tex-O-Kan (1941) indicates, this Fifth Circuit rule did not originate with Taft-Hartley; it has been "justified" in terms both of NLRB v. 
while denying reinstatement orders stemming from the same factual situation and, according to the Board, the same pattern of unfair labor practices. ${ }^{60}$

A Fifth Circuit decision ${ }^{70}$ denying enforcement to an order reinstating union organizers and supporters discharged from a non-union shop purportedly for failure to meet plant work standards ${ }^{71}$ was recently reversed by the Supreme Court ${ }^{72}$ in a per curiam decision which remanded the reinstatement order for reconsideration in a manner consistent with the rule of review established in NLRB v. Universal Camera Corp. ${ }^{73}$ The Court, finding that the Fifth Circuit had established a different standard of review for reinstatement cases, stated: "There is no place in the statttory scheme for one test of the substantiality of evidence in reinstatement cases and another test in other cases."74 Although neither the Court's opinion nor the lengthier dissent by Justices Frankfurter ${ }^{75}$ and Harlan suggests that the "for cause" proviso is

Jones \& Laughlin Steel Corp., 301 U.S. 1 (1937) [NLRB v. Walton Mfg. Co., 286 F.2d 15, 23 (5th Cir. 1961), rev'd, 369 U.S. 404 (1962)] and of the amendment to $\$ 10$ (c) [NLRB v. Fulton Bag \& Cotton Mills, 175 F.2d 675, 676 n.3 (5th Cir. 1949); NLRB v. Atlanta Coca-Cola Bottling Co., 293 F.2d 300 (5th Cir. 1961)].

69. E.g., NLRB v. Walton Mfg. Co., 286 F.2d 15 (5th Cir. 1961), rev'd, 369 U.S. 404 (1962) ; NLRB v. Florida Citrus Canners Co-op., 288 F.2d 630 (5th Cir. 1961); Frosty Morn Meats, Inc. v. NLRB, 296 F.2d 617 (5th Cir. 1961).

70. NLRB v. Walton Mfg. Co., 286 F.2d 16 (5th Cir. 1961), rev'd, 369 U.S. 404 (1962).

71. Walton Mfg. Co., 124 N.L.R.B. 1331 (1959). In Walton it was conceded that the plant manager was virulently anti-union, and the Fifth Circuit enforced a cease and desist order against employer practices such as surveillance of union organizers and coercion of workers known to be sympathetic to the union. The discharges occurred immediately after the dischargees' union activities. Compare Trial Examiner's discussion of the layoffs, 124 N.L.R.B. at 1349-75. Nonetheless, enforcement of the Board's reinstatement order was denied because there appeared in the record uncontroverted testimony by the employer that the women discharged were unable to keep their work up to plant standards. 286 F.2d at 22-24. Compare, however, the Trial Examiner's study, 124 N.L.R.B. at 1353-58, 1373. The court concluded that the Board's inferences with respect to the credibility of testimony about the reason for discharge were not supported by the record as a whole.

72. NLRB v. Walton Mfg. Co., 369 U.S. 404 (1962). A comparison case included in the Court's opinion, NLRB v. Fiorida Citrus Canners Co-op., 288 F.2d 630 (5th Cir. 1961), is less germane to the issues here.

73. 340 U.S. 474 (1951).

74. NLRB v. Walton Mfg. Co., 369 U.S. 404, 407 (1962) (emphasis added).

75. It is of more than passing interest that Mr. Justice Frankfurter, who was the author of Universal Camera, felt that NLRB v. Tex-O-Kan Flour Mills Co., 122 F.2d 433 (5th Cir. 1941) (see note 68 stpra), was not out of accord with that decision, however out of line it might have been with decisions respecting court revicw under the Wagner Act. See NLRB v. Nevada Consol. Copper Corp., 316 U.S. 105 (1942). Universal Camera, it should be remembered, was decided in a context which put chief emphasis on irtreased court supervision of NLRB decisions. See 340 U.S. at 490 ; NLRB v. Walton Mfg. Co., 369 U.S. 404, 419 (1962). Compare the Fifth Circuit's use of Universal Camera in NLRB v. Atlanta Coca-Cola Bottling Co., 293 F.2d 300, 308 n.13 (5th Cir. 1961). Walton, it would seem, approaches from the other direction, and can be viewed as a restriction rather than an enhancement of court review power. 
involved, ${ }^{76}$ it would appear that opposing interpretations of that clause are at the root of the difference between the Court and the Fifth Circuit. The circuit court treated the proviso as virtually precluding Board consideration of discriminatory employer motive whenever the employer could establish technical "cause" for the discharge in the employee's acts; it found that the statutory scheme had connmanded two rules of review. ${ }^{77}$ The Court's opinion implies that the Board still can and must make the primary determination of motive. Its rejection of the "two standards" is a repudiation of the special weight sought to be bestowed upon the existence of "cause," and hence a repudiation of the particular view of the "for cause" proviso taken by its supporters in the House of Representatives and by the Fifth Circuit. ${ }^{78}$ The Court's tacit interpretation of the proviso seems as applicable to discharges for strike misconduct as to those for plant inefficiency or misbehavior. Thus, a finding that cause exists, in the form of either plant or strike misconduct, does not preclude an inference of discrimination which constitutes a new and unremedied unfair labor practice under section 8(a) (3) of the act. The wording of the "for cause" proviso itself 70 compels this interpretation. The proviso requires not only that "cause" exist, but also that it be for cause that the employer resorts to dismissal. In other words, despite the difficulty of the inquiry, the very language of the provisoeven standing alone-must be read to forbid an employer's formally assigning as the reason for a discharge conduct constituting "cause," when his real

76. The "for cause" proviso has but rarely been cited in "assembly line" discharge situations such as these, although informal reference to "good" or "adequate" cause is often made. But compare NLRB v. Dixie Shirt Co., 176 F.2d 969 (4th Cir. 1949), and NLRB v. Sandy Hill Iron \& Brass Works, 165 F.2d 660, 662 (2d Cir. 1947), with NLRB v. Fulton Bag \& Cotton Mills, 175 F.2d 675, 676 n.3 (5th Cir. 1949).

77. Although NLRB v. Tex-O-Kan Flour Mills Co., 122 F.2d 433 (5th Cir. 1961) (see notes $68 \& 75$ stpra), does state "that the controlling and ultimate fact question is the true reason" for the discharge, it precludes the only pragmatic consideration of this question possible by giving the employer's sworn testimony about other "cause"-which will usually exist, given the imperfection of most employees-a preferred status. Id. at 438-39. This is the very practice to which the Walton Court objected. NLRB v. Walton Mfg. Co., 369 U.S. 404, 407 (1962).

78. See note 64 supra. It would seem that the Court's difference with the Fifth Circuit about the Board's fact-finding discretion can only be explained in these terms. There is an additional suggestion that this would be the Court's interpretation of the clause in its treatment in the more recent NLRB v. Washington Aluminum Co., 370 U.S. 9 (1962). That case involved discharges for spontaneous protest against working conditions in an organized plant; the company contended that it might properly discharge the participators for violating a company rule by leaving the premises without permission and for not giving the company "an opportunity to avoid the work stoppage by granting a concession." The Court refused to endorse a strict interpretation of the "for cause" proviso, implying that the proviso was no more than a statement of the rule, as recognized in NLRB v. Jones \& Laughlin Steel Corp., 301 U.S. 1 (1937), that motive is in each case a question of fact, independent of "cause," for the Board to determine. NLRB v. Washington Aluminum Co., 370 U.S. 9, 16-17 (1962).

79. Quoted in note 22 supra. 
motivation is in fact legitimate collective activity on the part of the employee. The discharge must not only be "for cause"-it must be "for cause."

Additional reasons compel an examination of employer motive in the strike misconduct situation, especially where the employer refuses to rehire some but not all of his delinquent employees. Because misconduct during unfair labor practices strikes usually follows acts of employer hostility to the union, the possibility that discharges of such employees will be discriminatory is greater than it is in the case where an employee appears to have been discharged for inefficiency. Furthermore, the context of the discharge markedly increases the employer's ability to conceal his true motivation by simultaneously discharging a few less important union members.

Arguably, however, upon finding that the discharge was discriminatory, the Board could nevertheless conclude that the policies of the act would not justify reinstatement in the absence of a formal discharge by the employer and thus could conclude that reinstatement was unwarranted. But the outcome of the balance between the two conflicting policies-the protection of legitimate collective activity and the fostering of peaceful and orderly settlement of labor disputes-would seem to be otherwise. The employer's discharge is, by definition, intended to destroy legitimate collective activity; a failure to reinstate in this situation allows the new unfair labor practice to have its intended effect, since no other remedy but reinstatement is available. Furthermore, although reinstatement might appear to condone or ignore the misconduct which made the employer's unfair labor practice discharge possible as well as compel the employer to take back persons who have demonstrated a flagrant disregard for his interests, other means are available to vindicate the public interest in restraining violence and intimidations by striking employees. The employer, by voluntarily allowing some of the workers guilty of misconduct to return to their jobs while rejecting others-on a discriminatory basis-has indicated that having such employees in his plant is not very disturbing to him; the employer's economic interest, moreover, would not seem to give him any special standing to mete out punishment on behalf of the public for unlawful strike misconduct, particularly where he has shown an intent to do so arbitrarily and for what is itself an unlawful purpose. Where non-strikers are injured by union violence, ${ }^{81}$ the NLRB could suspend its "automatic" reinstatement rule for unfair labor practice situations and order, as it does in connection with economic strikes, only that the employer must consider strikers on a non-discriminatory basis for those positions which he has not permanently filled since the union unfair labor practice. ${ }^{82}$ The guilty union might lose its representation rights for a period of time, as was sug-

80. The Thayer and Kohler courts, however, overlooked this point and directed their inquiry to the existence of cause, with the implication that this alone was sufficient to make the proviso operative. See notes 27-28 supra and accompanying text.

81. Either physically or economically.

82. NLRB v. Mackay Radio \& Telegraph Co., 304 U.S. 333 (1938). 
gested in the House bill which later became the LMRA, ${ }^{83}$ or be made to suffer other sanctions of a similar nature that would stop short of giving the employer arbitrary power over the jobs of its individual members. No statutory language warrants the conclusion that such power was intended to be reserved to employers in this special situation-and the explicit command of the statute seems to take away all employer power to use his discharge right for the illegal purpose of discouraging union membership or activity. It would seem that there is little justification for ignoring the problem of $8(a)(3)$ discrimination in the case of strike misconduct discharges, for the finding that a right to discharge exists should not be confused with the question of whether such right has been abused. The cases have apparently failed to make this distinction and thus have given approval to what is only an illusory command of the Fansteel decision.

83. 1 Legis. Hist. 68. 